\title{
Epilithic Diatom Abundance Study in the Batang Kuranji River in Padang City, West Sumatra
}

\author{
Mida Yulia Murni \\ Alumni of Study Program of Biology, Faculty of Mathematics and Natural Sciences, \\ Andalas University \\ Limau Manis, Pauh, Padang City, West Sumatra-25175, Indonesia \\ Corresponding author: midayulia0207@gmail.com
}

\begin{abstract}
A study about abundant of epilithic diatom was conducted on 2017 in Kuranji River. The objective of this study was to clarify species and abundant of epilithic diatom in Batang Kuranji River. Samples were collected in 3 stations by purposive sampling and brushing method. The results showed that totally 82 species in 22 genera had been found. The total abundant of epilithic diatom was 15139,26 individual $/ \mathrm{cm}^{2}$. The highest abundance of epilithic diatom was found in station I (Batu Busuak) and the lowest in station III (Sawah Liek). Synedra sp and Fragillaria sp were dominant group of diatoms which are found in almost all sites. Some physical and chemical water quality parameters were showed that Batang Kuranji River were polluted slightly by organic and inorganic materials.
\end{abstract}

Keyword: epilithic diatom; Batang Kuranji River; abundance; river pollution

\section{INTRODUCTION}

Epilithic diatoms are single-celled organisms that live and are attached to rock substrates. Diatoms are included in the Bacillariophyta division which can be used as a bioindicator of changes in environmental quality. The distinctive feature of diatoms is the presence of certain carvings on their cell walls consisting of epitheka and hypotension. The cell wall is composed of pectin and silica which have high resistance to environmental stresses [1].

The ecology that has been widely studied and its cosmopolitan distribution greatly influences aquatic life, so diatoms have varying adaptability from very vulnerable to high tolerance [2]. Diatoms emit a kind of gelatinous extrusion which provides adhesion to the rock where it attaches [3]. This causes epilytic diatoms to be able to inhabit water areas such as rivers for a long time and are difficult to move or drift.

Batang Kuranji River is a river in the Padang City area which is one of the watersheds in the Indragiri - Akuaman River Basin with a total area of $202.7 \mathrm{~km}^{2}$ watershed consisting of 5 sub-watersheds namely Batang Sungai Sapiah Watershed, Batang Danau Limau Manih Sub Watershed, Sub Batang Sungkai watershed, Batang Bukik Tindawan Sub-watershed and Batang Padang Janiah Subwatershed. Kurniawan [4] states that the Batang Kuranji River flows from upstream of the Bukit Barisan with the highest elevation about 1,858 meters above sea level at the peak of Bukit Tinjau Laut and empties into the
Padang coast with a main river length of about $32.41 \mathrm{~km}$ and the total length and all of its tributaries along 274.75 $\mathrm{km}$. Geographically the Batang Kuranji River is located between $0^{\circ} 48^{\prime}-0^{\circ} 56 \mathrm{LS}$ and $100^{\circ} 21^{\prime}$ - $100^{\circ} 33$ 'BT with an area of 22,431.29 hectare, has a flow that passes through Pauh sub-district, Kuranji sub-district, Nanggalo subdistrict and North Padang sub-district.

Annual rainfall in Padang City is between 3,500-4,000 $\mathrm{mm} /$ year which is included in the high rainfall category [5]. This potential rainfall is also one of the variables triggering the high level of disaster in the Batang Kuranji River flow. Debris flow is a disaster that is very feared to occur in the Batang Kuranji River because its flow crosses densely populated areas with steep topography and types of material forming the bottom and river banks that are easily released when exposed to water.

This high potential for disaster is caused by natural factors also caused by human activities that conduct sand and stone mining in this region. The activity resulted in the destruction of water building infrastructure and cliff protection due to local scouring. This will also have a negative impact on the biota that lives in this river including diatoms.

The purpose of this study was to determine the type of epilithic diatoms found in Batang Kuranji River, Padang City. In addition, this study also aims to analyze the abundance of epilithic diatoms found in Batang Kuranji River, Padang City. 


\section{METHODS}

\section{Location}

The study was conducted in Batang Kuranji River, Padang City, West Sumatra. Geographically this location is located between $0^{\circ} 48^{\prime}-0^{\circ} 56^{\prime} \mathrm{LS}$ and $100^{\circ} 21^{\prime}-100^{\circ} 33^{\prime} \mathrm{BT}$. The time needed for research is from February to April 2017.

\section{Materials and Tools}

The materials used are epilithic diatom groups collected at each station and water samples obtained from each station for laboratory analysis purposes. The tools used during the study were sample bottles, brushes, frame size of $20 \times 20 \mathrm{~cm}^{2}$, scale rope, scale stick, thermometer, SCT meter, $\mathrm{pH}$ indicator, and $0.45 \mu \mathrm{m}$ millipore paper for the analysis of dissolved solids, spectrophotometers, microscopes, object glasses, cover glass, dropper pipette, and microalgae identification book A beginner's guide to freshwater algae by Belcher and Swale [6] and Freshwater Algae: Identification and Use as Bioindicators by Bellinger and Sigee [7].

\section{Methods}

Sampling was carried out using the purposive sampling method at 3 station points located upstream of the river. The determination of the sampling station was based on a description of the location around the river. Station 1 was at the headwaters of the river which was located in the Batu Busuk area.

At this location the condition of the river was clear, a lot of large rocks and fast flowing. Station 2 was located in the Korong Gadang area which was an excavated area C. While station 3 was located at the intake channel of the Padang PDAM intake in the area of J1. Liek rice field. At this station various anthropogenic activities of the people living on the banks of the Batang Kuranji River were found.

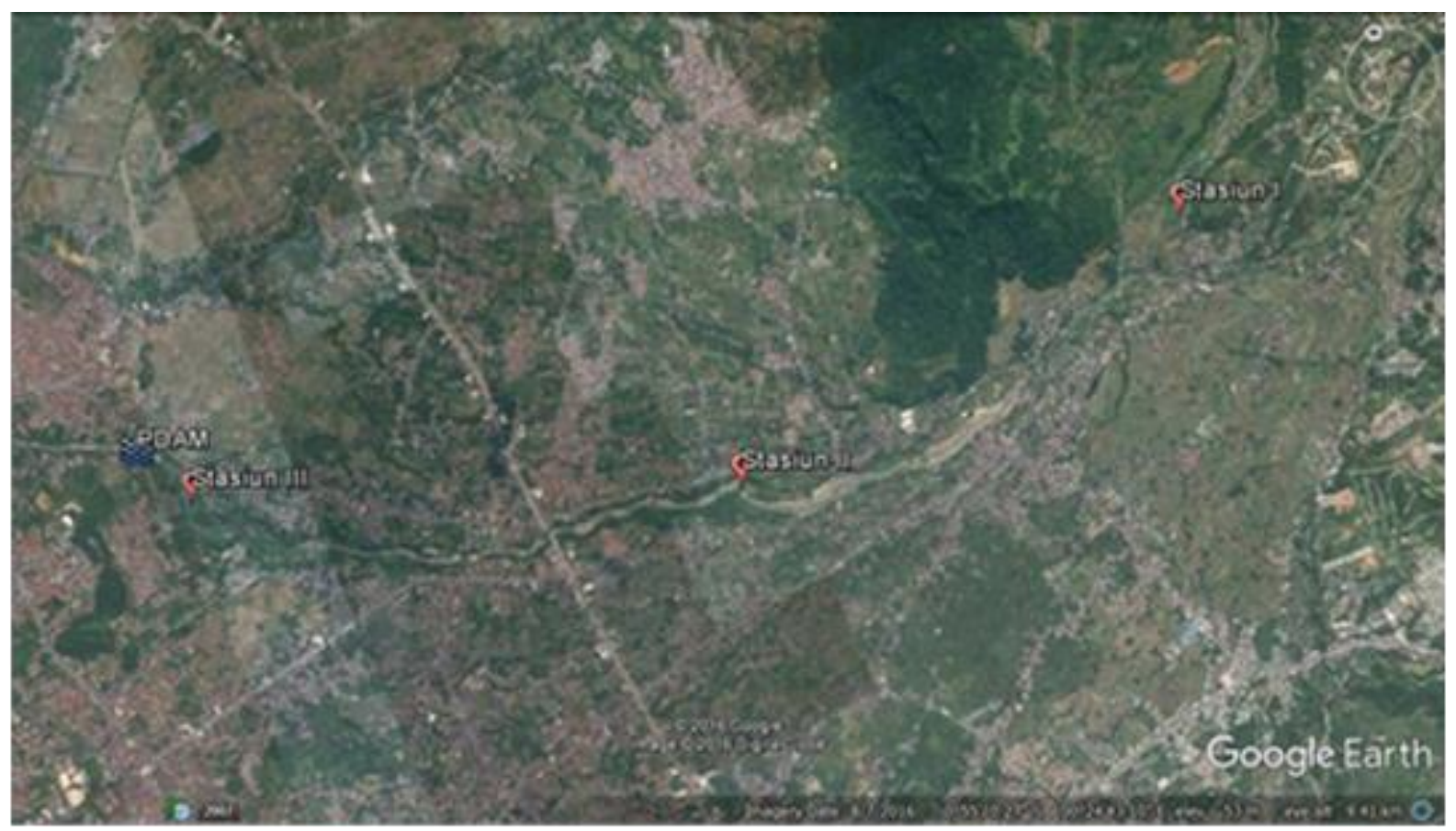

Figure 1. Map location of epilytic diatom sampling in Batang Kuranji River

\section{Sampling}

Sampling of diatom organisms was done by scraping the surface of the rock substrate using a brush. The surface area of each stone's scrap was $20 \times 20 \mathrm{~cm}^{2}$. The scrap was sprayed with $30 \mathrm{~mL}$ distilled water and then preserved using a Lugol $1 \%$ solution for laboratory analysis. Sampling of water was carried out simultaneously with diatom sampling at each station. The sample water was put into a $1 \mathrm{~L}$ volume sample bottle for laboratory analysis purposes.

\section{Measurement Parameters}

\section{a. Aquatic Physics-Chemical Parameters}

The chemical physics parameters of in situ waters include temperature, flow velocity, depth and turbidity of the river, $\mathrm{pH}$, and dissolved oxygen (DO). The ex situ parameters consist of Total Suspended Solid (TSS), Total Dissolved Solid (TDS), Electrical Conductivity (DHL), Biological Oxygen Demand (BOD5) Chemical Oxygen Demand (COD), nitrates, orthophosphate, and total phosphate. Measurement of all the physical chemical parameters of the waters refer to the APHA 2012 standard method [8]. 
TABLE I

HYDROLOGICAL MEASUREMENT OF BATANG NAREH RIVER

\begin{tabular}{lccc}
\hline \multicolumn{1}{c}{ Parameters } & Station 1 & Station 2 & Station 3 \\
\hline Flow velocity $(\mathrm{m} / \mathrm{sec})$ & 0,40 & 0,53 & 0,32 \\
The average depth $(\mathrm{cm})$ & 27 & 23 & 23 \\
River Width $(\mathrm{m})$ & 13,47 & 16,75 & 18,03 \\
Width of the river $(\mathrm{m})$ & 15,69 & 19,65 & 18,72 \\
\hline
\end{tabular}

b. Abundance of epilithic diatoms

An epilithic diatom density calculation was performed to determine the number of individuals per diatom taxa per $\mathrm{cm}^{2}$ found per station. The average surface area of the scraped stone is $20 \times 20 \mathrm{~cm}^{2}$. To calculate the abundance of epilithic diatoms, the formula Michel [4] was used as a guide for data processing. How was the identification method? Please explain may be one or two sentences

$$
\mathrm{N}=\frac{(\mathrm{a} \times 1000) \times \mathrm{C}}{\mathrm{L}}
$$

$\mathrm{N}$ : plankton abundance (ind $/ \mathrm{cm}^{2}$ )

a: the average number of plankton in $1 \mathrm{ml}$

$\mathrm{C}$ : concentration of filtered water volume

$\mathrm{L}$ : the area of the scrap

c. Data Analysis

The abundance of epilytic diatom identification results was calculated using the help of Microsoft Excel software. The diatom abundance analysis was carried out using the help of Minitab 16 and SPSS 15.0 software.

\section{RESULTS AND DISCUSSION}

From the research that has been carried out in Batang Kuranji River from February to April 2017 in three Stations, 82 diatoms were classified into 22 genera. Based on the results of research in all observation stations, there are 13 types that dominate the river waters. The species with the highest total abundance was Synedra affinis with a total of $893.49 \mathrm{ind} / \mathrm{cm}^{2}$. This type of diatom was known to be able to survive in a low nutrient environment [9].

The species that have the smallest total abundance, were found as many as 7 types including Cymbela obscura, Encyonema minutum, Fragilaria brevistriata, Frustulia rhomboids, Nitzschia acicularis, Nitzschia amphibia and Stauroneis producta individual per $\mathrm{cm}^{2}$. While other species were found little or only in one station and not found in another station. Any data on the abundance based on genera? Put them in histogram describing abundance per genera. The results of the analysis of the physical and chemical factors of the Batang Kuranji river water before the PDAM intake was presented in Table II.

TABLE II

RESULTS OF PHYSICAL AND CHEMICAL FACTOR ANALYSIS IN BATANG KURANJI RIVER

\begin{tabular}{|c|c|c|c|c|}
\hline Parameter & Unit & Station 1 & Station 2 & Station 3 \\
\hline \multicolumn{5}{|l|}{ Physics } \\
\hline Temperature & $\left({ }^{\circ} \mathrm{C}\right)$ & 25.6 & 27.5 & 27 \\
\hline DHL & $\mathrm{mS}$ & 1.8 & 1.4 & 1.8 \\
\hline Turbidity & (NTU) & 4.67 & 45.52 & 47.53 \\
\hline TSS & $\mathrm{mg} / \mathrm{L}$ & 25 & 40 & 45 \\
\hline TDS & $\mathrm{Mg} / \mathrm{L}$ & 28 & 35 & 33 \\
\hline \multicolumn{5}{|l|}{ Chemistry } \\
\hline $\mathrm{pH}$ & - & 6.56 & 6.82 & 6.87 \\
\hline DO & $\mathrm{mg} / \mathrm{L}$ & 6.74 & 5.44 & 5.32 \\
\hline $\mathrm{BOD}_{5}$ & $\mathrm{mg} / \mathrm{L}$ & 3.34 & 4.14 & 4.40 \\
\hline Nitrate $\left(\mathrm{NO}_{3}\right)$ & $\mathrm{mg} / \mathrm{L}$ & 0.067 & 0.110 & 0.072 \\
\hline O-Phosphate $\left(\mathrm{O}-\mathrm{PO}_{4}\right)$ & $\mathrm{mg} / \mathrm{L}$ & 0.034 & 0.066 & 0.050 \\
\hline Total Phosphate $\left(\mathrm{T}-\mathrm{PO}_{4}\right)$ & $\mathrm{mg} / \mathrm{L}$ & 0.085 & 0.087 & 0.082 \\
\hline
\end{tabular}

The results of the analysis of chemical physics factors of Batang kuranji River conducted during field sampling can be influenced by activities involving the river. This causes an increase in input material into the river and will certainly affect the life of river biota including epilytic diatoms [10]. Each epilithic diatom species has a certain level of tolerance to its environment. Aprisanti [11] stated that epilithic diatoms will grow and develop well if their environment is within the tolerance limits that can be tolerated by epilithic diatoms. 


\section{Abundance of Epilithic Diatoms in the Batang Kuranji River}

Based on research conducted in Batang Kuranji River, the total abundance of eepilithic diatom individuals obtained in sampling 1 (February 2017) was 5377.8 ind $/ \mathrm{cm}^{2}$. While the total abundance of individuals in sampling 2 and 3 in March and April 2017 were 4937.8 and $4823.7 \mathrm{ind} / \mathrm{cm}^{2}$ respectively with a total sample of $15139.26 \mathrm{ind} / \mathrm{cm}^{2}$. The results of identification of epilithic diatom types found were 82 species belonging to 22 genera.

The highest average abundance of epilithic diatoms in each sampling was found in sampling 1 with an average abundance of $1792.6 \mathrm{ind} / \mathrm{cm}^{2}$. Then in sampling 2 the average abundance of diatoms was $1645.9 \mathrm{ind} / \mathrm{cm}^{2}$. Whereas at station 3 , the average abundance of diatoms was $1607.9 \mathrm{ind} / \mathrm{cm}^{2}$. Previous research had been conducted by Afrizal [12] entitled Abundance and Epilytic Diatom Spread on the River around Andalas University Campus. In that study as many as 40 types of epilithic diatoms were found in rivers around the Unand campus. One type found was Coconeis placentula. This type of epileptic diatom was only found at station 1 and a little at station 3 which is a biological indicator for clean water.

\section{CONCLUSION}

The total abundance of epilytic diatom individuals found in the Batang Kuranji River during 3 sampling periods is $15139.26 \mathrm{ind} / \mathrm{cm} 2$ which belongs to 82 species of 22 genera. The species with the highest total abundance is Synedra affinis with a total abundance of $893.49 \mathrm{ind} / \mathrm{cm} 2$. While species that have the smallest total abundance of $39.32 \mathrm{ind} / \mathrm{cm} 2$ were found as many as 7 types including Cymbela obscura, Encyonema minutum, Fragilaria brevistriata, Frustulia rhomboids, Nitzschia acicularis, Nitzschia amphibia and Stauroneis producta. From the research that has been carried out, it is hoped that it can be continued to find out river water quality based on epilytic diatoms in each river in West Sumatra in particular and Indonesia in general.

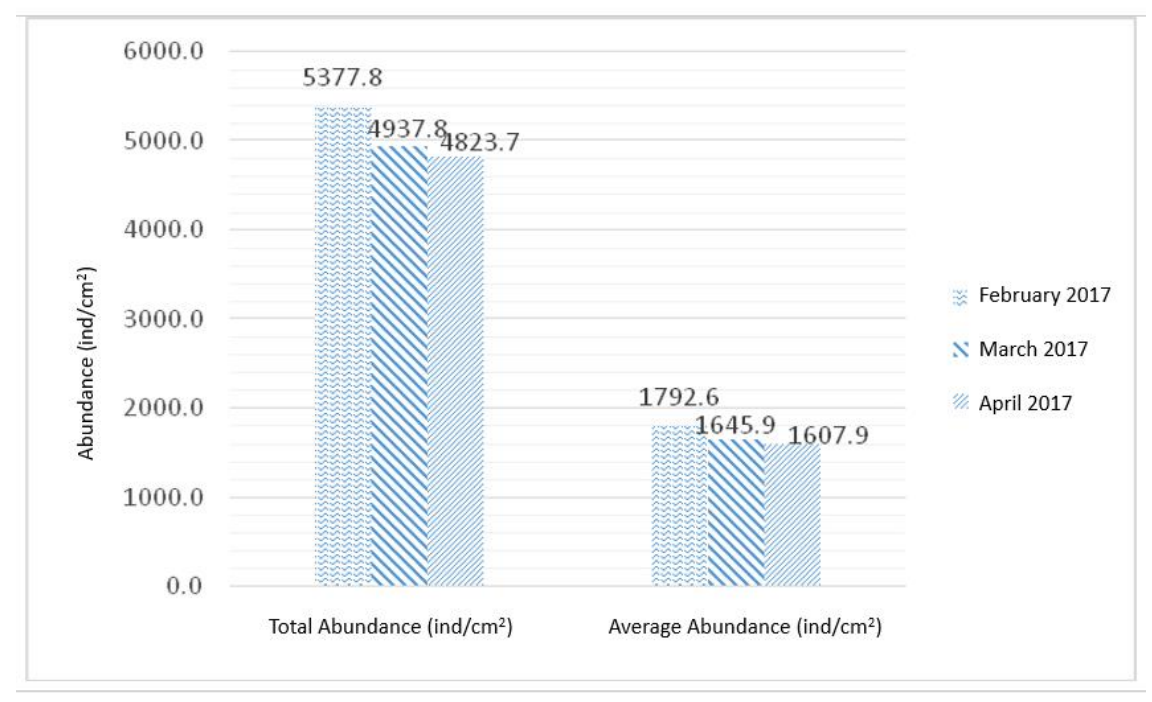

Figure 2. Total and average abundance based on the sampling period

\section{REFERENCES}

[1] Stoermer EF, JP Smol. 2001. The Diatoms: Applications for the Environmental and Earth Sciences. Cambridge University Press

[2] Pasisingi N. 2014. Diatom Epilitik Sebagai Indikator Kualitas Air Di Bagian Hulu Sungai Cileungsi, Bogor. Thesis IPB. Bogor

[3] Siregar SH, A Mulyadi, OJ Hasibuan. 2008. Struktur Komunitas Diatom Epilitik (Bacillariophyceae) Pada Lambung Kapal Di Perairan Dumai Provinsi Riau. Journal of Enviromental Science, Universitas Riau. Pekanbaru.

[4] Kurniawan H. 2014. Penilaian Tingkat Kekritisan Daerah Aliran Sungai (DAS) Batang Kuranji Kota
Padang Berdasarkan Biofisik. Thesis Unand. Padang.

[5] Badan Meteorologi Klimatologi dan Geofisika. 2016. Buletin Prakiraan Musim Hujan 2016-2017 Propinsi Sumatera Barat. Jakarta

[6] Belcher H, E Swale. 1978. A beginner's guide to freshwater algae. Natural Environment Research Council. Combridge.

[7] Bellinger EG, DC Sigee. 2010. Freshwater Algae: Identification and Use as Bioindicators. Wiley, John and Sons, Ltd.

[8] Rice EW, RB Baird, AD Eaton, LS Clesceri. 2012. APHA (American Public Health Association): Standard Method for the Examination of Water and Wastewater 22th ed. Washington DC. 
[9] Venter A, A Jordaan, AJH Pieterse. 2003. Oscillatoria simplicissima:A taxonomical study. School of Environmental Sciences and Development: Botany. South Africa. Journal Water SA, 29: 1.

[10] Ravera O. 2001. Monitoring of the aquatic environment by species accumulator of pollutants. Journal of Limnology, 60: 63-78.

[11] Aprisanti R, A Mulyadi, SH Siregar. 2013. Struktur Komunitas Diatom Epilitik Perairan Senapelan dan Sungai Sail, Kota Pekanbaru. Jurnal Ilmu Lingkungan, pp. 244-246.

[12] Afrizal, S. 2008. Kelimpahan dan Penyebaran Diatom Epilitik Pada Sungai Sekitar Kampus Universitas Andalas. Unand. Padang.

[13] Sloane E. 2003. Anatomi dan Fisiologi untuk
Pemula, Alih Bahasa J.Veldman, Jakarta, EGC, pp. 290-291.

[14] Wahyuni HI, NP Roxas. 2008. Comparative Study of Pancreatic Enzyme Activity and It's Histology In Native And Broiler Chicks, Prosiding Seminar Nasional Teknologi Peternakan dan Veteriner 2008, pp. 678-683.

[15] Bhatia D, MK Gupta, A Bharadwaj, M Pathak, G Khatiwas, M Singh. 2008. Anti-diabetic Activity of Centratherum Anthelminticum Kuntze on Alloxan Induced Diabetic Rats. Pharmacologyonline, 3:1-5.

[16] Purnomo MT. 2010. Pengaruh Diet Singkong (Manihot esculenta) terhadap Struktur Histologi Pankreas Tikus Putih (Rattus norvegicus), Surakarta, UNS. 